\title{
Ecocriticism \& Irish Poetry A Preliminary Outline
}

\author{
James Mc Elroy \\ The University of California, Davis
}

Copyright (c) 2011 by James Mc Elroy. This text may be archived and redistributed both in electronic form and in hard copy, provided that the author and journal are properly cited and no fee is charged for access.

\begin{abstract}
This article offers a brief thumbnail sketch of how Irish poetry has situated "nature" inside its competing narrative forms. Beginning with Irish poetry's earliest lyrics and concluding with some of Ireland's most recent, and most experimental, writers, the goal of the piece is to introduce some rudimentary eco-critical theory as a means of better understanding how nature acts as a complex cultural and political semiotic, so often overlooked, in Irish literature. En route, the article examines and in part deconstructs those critical categories that have often divided Irish literature into two distinct ecological camps: the picturesque (read colonialist/tourist) and the oral (read native/indigenous). The article also considers the importance of ecofeminist theory and asks how critics might better read Ireland's women poets as nature poets in their own right. In closing, the piece turns its attention to a number of recent poets, both men and women, who have exceeded the picturesque/oral divide and now require eco-alternative readings of nature as we enter the second decade of the $21^{\text {st }}$ Century.
\end{abstract}

Key Words. Nature, ecocriticism, picturesque, oral, ecofeminisim

Resumen. El artículo ofrece una breve reseña de cómo la poesía irlandesa ha situado a la "naturaleza" en el centro de sus variadas formas narrativas. Empezando con las primeras piezas líricas de poesía irlandesa y concluyendo con alguno de los escritores más recientes y experimentales de Irlanda, el propósito de este trabajo consiste en introducir los rudimentos de la teoría eco-crítica con el fin de dar cuenta de un tema tan pasado por alto en la literatura irlandesa como es el papel de la naturaleza como compleja semiótica política y cultural. De paso, el artículo examina, y en parte deconstruye, esas categorías críticas que a menudo han escindido a la literatura irlandesa en dos campos ecológicos: lo pintoresco (léase colonialista/turista) y lo oral (léase nativo/autóctono). El artículo considera asimismo la importancia de la teoría ecofeminista y se pregunta de qué manera podrían los críticos mejorar su lectura de las poetas irlandesas en tanto que poetas de la naturaleza por derecho propio. El trabajo concluye prestando atención a una serie de poetas recientes, tanto hombre s como mujeres, que han sobrepasado la división pintoresco/oral y que, al iniciarse la segunda década del siglo XXI requieren aproximaciones eco-alternativas de la naturaleza.

Palabras clave. Naturaleza, ecocrítica, pintoresco, oral, ecofeminismo.

Kuno Meyer claims, in Selections from Ancient Irish Poetry, that an intense love of nature "in its tiniest phenomena as in its grandest, was given to no people so early and so fully as to the Celt" (Meyer 1959: xii). Seamus Heaney strikes much the same pose as Meyer when he writes that Ireland's ancient nature verse "makes a springwater music out of certain feelings in a way unmatched in any other European language" (Heaney 1980: 182). 
Heaney also admires Kenneth Hurlstone Jackson who insists that Celtic literature "did not belong at all to the common culture of the rest of Europe; nor did it ever become more than partly influenced by it" (Heaney 1980: 183). Elsewhere, Jackson adds that even though Celtic literature was never more than partly influenced by European culture it did, at some point after the twelfth and thirteenth centuries (because of "foreign influences"), start to lose its "earlier spontaneity" (Jackson 1935: vii). Patrick C. Power agrees that nature verse was of immense importance before the $13^{\text {th }}$ Century but believes that fewer and fewer nature poems were written after that time (Power 1967: 124). Seán Ó Tuama supports the basic thesis that Old/Middle Irish was awash in nature references and that things started to deteriorate at some point thereafter (Ó Tuama 1995: 263). Where Ó Tuama differs from some of the aforementioned critics, however, is that he thinks Ireland's nature verse only went into serious decline from 1601 on (Ó Tuama 1981: xxix).

Whatever critical value these different ecological notations possess, the significance of nature writing in the earlier stages of Irish literature, coupled with a diminution of interest in nature over time, requires much more scholarship before any critical verdict can be handed down. That said, it is clear that all the above critics share an ecocritical perspective concerning the Irish and their fondness for nature; a fondness which is supposed to stretch back to a pre-Christian era when humans and nature existed in a state of virtual bliss. It is also clear that such narratives provide a longstanding semiotic of nature discourse whereby the English imperium, not Roman Christendom or Europeanism, is held responsible for negating Ireland's topographic realm and creating a divisive universe characterized by destructive agricultural practices, the systematic exploitation of natural resources (in particular, the felling of native trees), and, at the level of language, literature and culture an ongoing ideological representation of the Irish people as uncivilized others - wild, savage, etc.

When Michael Viney writes in "Woodcock for a Farthing: The Irish Experience of Nature" that Irish and English views of nature have seldom coincided his statement is thus part truism, part understatement (Viney 1986: 59). Likewise, when Viney explains that in the sixteenth and seventeenth centuries the English espoused an ideal type of "the land" and insisted it be cultivated in their image and likeness, he is quick to recognize that the Irish were never in any position to meet the excruciating demands of those who labeled them "wood-born savages"; as he later puts it with sardonic twist, "English destruction of the Irish woods was thus an act of civilization" (Viney 1986: 59). Rebecca Solnit makes much the same point as Viney in A Book of Migrations: Some Passages in Ireland where she observes, with respect to the sixteenth century, that not only did Spenser and Sidney then lay the groundwork for the English pastoral tradition but, in so doing, ensured that the viability of - the very idea of - a credible Irish pastoral was ruled out of court (Solnit 1997: 103-104). Solnit dwells on this ideological ruling further when she asks, with a calculated sense of naiveté, "Does the English pastoral, and the security and abundance it represents, depend on the impoverished land and people of other lands?" (Solnit 1997: 103104).

In empirical terms, at least, the answer to Solnit's question involves, and this accords with Ó Tuama's position, the wholehearted destruction of Ireland's woods following Irish defeat at Kinsale in 1601: an Ireland that was still under substantial forest in 1600 had, by 1711, become a "treeless wilderness and a net importer of timber" (Solnit 1997: 104). Such material exploitation also paved the way for some of the most embattled/embittered views of nature which were to come into even sharper relief after The Famine when, according to Viney, the Irish lost their hold on, and began to doubt the efficaciousness of, nature and their connection to it: "In the biological treachery of the Famine, nature was disgraced: it would not be surprising if, somewhere in the rural consciousness, a decision was made neither to grant nor expect any further quarter" (Viney 1986: 62).

Eamon Slater (1993) argues that the systematic exploitation of Ireland's physical environment coupled with the "biological treachery" of The Famine perpetuated specific material and social conditions which determined the outline of two broad-based paradigms, the picturesque and the oral, and that it was the interchange between these two competing paradigms which came to define Ireland's eco-discourses as known. Slater goes 
on to argue that the first of these paradigmatic positions, the "picturesque", registers a measure of detachment which befits a landlord, outsider or tourist class whereby the English and their surrogates are able to sanction a worldview devoid of wilderness, work and hardship so that colonial order (in miniature, the demesne) might serve as iconic representation; among other things, might minimize indigenous presence along with any native categories pertaining to Ireland's ecological/natural space. And, yes, one of the most crucial of these eco-colonial spaces was the garden as situated inside Anglo-Ireland's landed estates (Slater 1993: 24). Indeed, it was through the medium of such elegant and expansive gardens, says Slater, that the AngloIrish were able to differentiate themselves from those scores of impoverished tenants whose very presence invoked powerful contrast: if nature within the perimeter walls of the great estates constituted what was civilized and "picturesque", then that which lurked outside the graduated borders of such reserves was deemed to be uncivilized wilderness.

Just as the Anglo-Irish adjudicated the empirical circumstances of nature inside their walled estates, they also controlled (subaltern narratives withstanding) how nature narratives were constructed, construed, and constrained outside the demesnes. When W.B. Yeats told J.M. Synge to go to the Aran Islands and "express a life that has never found expression" - "Live there as if you as if you were one of the people themselves" - he thus occasioned Synge to provide an account of nature in an inhospitable, i.e., unwooded, location (Yeats 1982: 63). As it happens, the colonial measure of Yeats's initial command, coupled with Synge's final product, The Aran Islands, provides an engaging account of ecological conditions on the Arans while substantiating some of the most prepossessive ideological values inherent in the Anglo-Irish worldview including the use of the sublime, as concept, to absorb the ragged/rugged features of Irish landscape within Synge's chosen mode of picturesque reference. The same mode of reference is also, as Tim Robinson points out, quite selective in that Synge's narrative constructions exclude a number of imposing landmarks - a large cashel next to his digs, an enormous storm beach, and the imposing presence of Dūn Aonghasa - and so gloss over any questions that might arise with reference to their geo-historical origins (Robinson 1992: xlii).

The kind of ideological "suppression" (Robinson's term) Synge engages in thus confirms rather than questions Anglo-Irish views of nature. It also supports both his and Yeats's shared belief in Ireland's environment as suitable habitat for a resident population of noble savages: "The absence of the heavy boot of Europe has preserved to these people the agile walk of the wild animal" (Synge 1992: $21)$. Synge augments this view of the noble savage when he writes that the islanders have "never been acted on by anything much more artificial than the nests and burrows of the creatures that live round them" (Synge 1992: 21). He also affords, and this is crucial, a narrative which subordinates the oral accounts his island hosts present as significant: the islanders' transubstantive language practices, including their views of nature, are relegated to subordinate status while Anglo-Irish taxonomies are allowed to define the oral tradition in question (and it is in question) through a medium of political correctness wherein Ireland's noble savages are presented as a species type in need of someone to better explain - translate - what their savage ways might mean for, or to, civilized man.

A similar ideological approach, though this time the concentration is botanical, is also found in the prodigious studies of Robert Lloyd Praeger who, as Sean Lysaght notes in his biographical account of same, turned some of Ireland's western islands into a "locus of investigation and representation" (Lysaght 1998: 55). According to Lysaght, Praeger's work on Clare Island became for botanical field studies what the Aran Islands had been for Synge: "The western island was a microcosm of native integrity and it functioned powerfully as a representative site for a wide gamut of patriotic, nativist or separatist feeling" (Lysaght 1998: 55). Lysaght also thinks that endemism, in the hands of Praeger, provides a close scientific complement to the more fashionable brands of Celticism that were in vogue during the revival period (Lysaght 1998: 85). While Praeger's field studies are laudable, and there can be no doubt about the sheer range of his botanic research, his work serves as another reminder that Anglo-Irish ecologism often assumes as much as it explains: for one thing it assumes that England, even when its botany is seen to represent a 
a counterpoint to that of Ireland, nevertheless remains the centrific point of botanical definition; for another, it assumes that it is best to define Ireland's plant life along a teleological line which subordinates and subverts Irish and Irish-language taxonomic reference points vis-à-vis established plant communities and habitat formations (Lysaght 1998: 86).

As an Aran native, Liam O'Flaherty provides, if only in relief, an alternative to some of the teleological narratives scripted by Synge and Praeger. So while it is true, as Richard Thompson points out, that O'Flaherty's stories have their shortcomings imprecision, oversimplification, exaggeration they nevertheless permit certain facets of native island discourse, and this includes islandic perspectives on how to designate "nature", to figure in their eco-based narratives (Thompson 1983: 80-97). Such an ecological perspective is readily available in "The Wounded Cormorant" where O'Flaherty records, with dispassionate interest, the fate of a bird which has been incapacitated through no fault of its own: "Cast out from the flock, death was certain. Sea-gulls would devour it" (O'Flaherty 1956: 109). As it turns out, and this reflects O'Flaherty's standard ecological practice, "The Wounded Cormorant" finds its narrative conclusion in a moment of existentialism: "it fluttered its wings twice and lay still. An advancing wave dashed it against the side of the black rock and then it disappeared, sucked down among the seaweed strands" (O'Flaherty 1956: 110).

According to James H. O'Brien (1973: 110) this story and stories like it provide an introduction to the "uninhibited" forces of nature. O'Brien also thinks that the way O'Flaherty foregrounds nature provides a partial alternative to the ecological works of Anglo-Irish writers like Yeats and Synge (109). Amy Scher extends O'Brien's critical position by advancing the view that O'Flaherty was one of the first Irish writers in the twentieth century to express a genuine "ecological sensitivity" (Scher 1994: 113). Scher further insists that the true measure of O'Flaherty's ecological disposition is how much he favors those situations where human beings maintain a relationship with the earth based on "interdependence" and that whenever human beings enter into a relationship based on independence things go awry (121-2).
Another Aran native, Máirtín Ó Direán, also favors a certain measure of interdependence. It is interesting to note, for example, how much interdependence Ó Direáin allows when he writes about his home place as a difficult islandic space and chastises Synge, in "Homage to John Millington Synge", for his failure to heed the island's primordial call: "Nior éistis scéal na gcloch" / "You didn't listen to the tale of the stones" (Ó Direáin 1984: 40-1). In "Aran 1947”, Ó Direáin once again returns to his "tale of the stones" when he writes, "Ni don óige feasta / An sceirdoileán cúng úd": "Not for the young any more, / That narrow windswept island" (16-7).

Needless to say, the Aran Islands (and Praeger's Clare Island) are not the only offshore locations featured in the pages of Irish literature: while the Aran Islands might have been Synge's first choice - more accurately, Yeats's first choice - in the search for pure unadulterated Irishness, once other people started to visit the Arans in any numbers he, Synge, "fled" to the Blasket Islands (Yeats 1976: 492). Interestingly enough, it is out of the same Blaskets that another line in native Irish writers emerged; writers who, like O'Flaherty and Ó Direáin, relished the draw of nature - this notwithstanding Nic Dhiarmada's (2008: 55) comments on the anti-utopian strain in Irish-language writing - as an engaging feature of life in a place of bleak beauties.

Perhaps the most famous of these Blasket accounts are Peig Sayers' An Old Woman's Reflections and Peig: The Autobiography of Peig Sayers of the Great Blasket Island though E.M. Forster thinks that Maurice O'Sullivan's Twenty Years A-Growing provides the landmark account of life on the Blaskets from "inside" (Forster 1933: ii). Tomás Ó Crohan's The Islandman provides another influential "inside" - account of Blasket life covering everything from lobster fishing to seal hunting. John Wilson Foster characterizes Ó Crohan's work, in his article "The Culture of Nature", as a work of "hostile recalcitrance" and insists it has a lot more in common with Defoe than with Synge who, he says, "suffuses the harshness of the western landscape with Romantic elegiac poetry" (Foster 1997: 610). In another article entitled, "Nature and Nation in the Nineteenth Century", the same Foster equates Synge's elegiac verse with Yeats's quest to transform Ireland's topographical/ ecological otherness into literary pastoral; 
he concludes that both narrative approaches, though different in kind, represent occasions of "cultural colonization" (Foster 1997: 422).

Yeats's "Coole Park, 1929", "I meditate upon a swallow's flight, / Upon an aged woman and her house, / A sycamore and lime tree lost in night", and its companion piece, "Coole and Ballylee, 1931", "Under my window-ledge the waters race, / Otters below and moor-hens on the top", are both written in such a pastoralist mode of reference (Yeats 1996: 242-3, 243-5). A narrative mode which makes David Lloyd argue - and this even though "Coole and Ballylee, 1931" appears to offer a "referential description" of river habitat - that Yeats's work codifies an "arrogant indifference to the actual landscape" (Lloyd 1993: 65). Lloyd's position is reinforced by Barbara Hardy who believes that Yeats's nature references are nothing more than "emotional correlatives" (Hardy 1990: 68). But it is Richard Wilbur who levels the harshest criticism against Yeats when he turns to "The Lake Isle of Innisfree" and makes the following statement: "Those beans, and the implication of manual exertion, are incongruous, and we are put in mind, by contrast, of Henry David Thoreau, whose beans, whatever else he made of them, were in the first place actual" (Wilbur 1976: 154). Wilbur follows up this criticism by taking Yeats to task one more time for his poetic "reverie":

For such a poet there can be only a limited sense of place, and even the rocks and moorhens of the later verse are symbols which seldom threaten to assert a life of their own. The celebrated 'Lake Isle of Innisfree' is not an island at all, but a projection in natural images of the state of reverie (Wilbur 1976: 154).

This projective need to define a "limited sense of place" in order to sustain a specific mode of ecological production is also to be seen in the work of Richard Murphy who treats nature with a level of critical awareness which, even though it supersedes the ecopolitics of Yeats, Synge, Praeger, continues to operate inside a variant of the "picturesque". On some occasions, it is true, this practice can involve direct comment about Murphy's ancestors as planters who once "bulldozed three bronze-age raths" (Murphy 2000: 65). On other occasions it can involve, as he makes clear in his memoir, The Kick, some personal reminiscence from inside the Anglo-Irish demesne as a walled place surrounded by "immense bog": "Beyond the garden wall, too high to climb an immense bog stretched as far as we could see, from the upstairs study window through the branches of a yew tree, to the pale blue hill of Castlehacket on the horizon" (Murphy 2002: 48).

As much as Murphy might frown upon the colonial practices of his forebearers, his core values regarding nature survive on a strict diet of images out of the same "West" which was once so popular, so requisite, among the Anglo-Irish revivalists of the 1890s. In fact, it could be argued that one of the main reasons Murphy takes refuge in Ireland's remote western regions so often is precisely because such eco-locales let him isolate "nature" while maintaining a beneficent distance between himself and the less glamorous realities of local, indigenous existence. This ironic circumstance, central to the efficiencies of a picturesque mode of representation, means that Murphy can thus enjoin competing ecological viewpoints as part of his oeuvre: in poems like "High Island" can assure a return to sites where he realizes "An older calm, / The kiss of rock and grass" (Murphy 2000: 135), while, in poems like "Planter Stock", can issue a sustained meditation on his position as a surviving member of an Anglo-Irish class whose view of nature goes something like this:

People look up to me, though I'm falling down, And wonder why a monkey-puzzle tree Chose to ascend from seaweed a hard mountain Where gorse-gold standard plunges into scree.

I love old watercolours curlews paint With iodine on a quill down a glen's throat; Deplore the weather's poor mouth complaint; Wear fuschia tweed, an ancient ivy coat.

Can't you eat rabbit? Does it make you sick To find your father's gun-shots in your meat, Or touch a trout he's caught? You ought to like Wearing an Eton collar; you look sweet.

(Murphy 2000: 198)

For Patrick Kavanagh “the weather's poor mouth complaint" signifies something quite different: in contrast to Murphy's "ancient ivy coat", Kavanagh's ingrained sense of nature is linked to the "scraidins of farmers with their watery little hills that would physic a snipe" (Kavanagh 1975 a: 9). It is only right, then, that Kavanagh should be the one to offer a few sobering thoughts, in The Green Fool, about the indigenous ("oral") view of nature circa 
1938: "There was no love for beauty. We were barbarians just emerged from the Penal days. The hunger had killed our poetry and we were mere animals grabbing at the leavings of the dogs of war" (Kavanagh 1975b: 63). There are several passages just like this one in Tarry Flynn where Tarry, Kavanagh's front man, reflects on his fondness for nature as if it was a serious character flaw; as if it was a source of beatific shame: "Stones, clay, grass, the sunlight coming through the privet hedge. Why did he love such common things? He was ashamed of mentioning his love; these things were not supposed to be beautiful" (Kavanagh 1978: 172).

Whether Kavanagh recounts the significance of local plant life in "On Reading a Book on Common Wild Flowers", "The burnt saxifrage was there in profusion / And the autumn gentian - / I knew them all by eyesight long before I knew their names", or celebrates, as he does in the later "Canal Bank Walk", "The will of God, wallow in the habitual, the banal, / Grow with nature again as before I grew", his overriding concern is with the parish as a limited and liminal - but luminous - habitat space (Kavanagh 1964: 137, 150). To therefore write, as Klejs does ("Seed Like Stars: Kavanagh's Nature"), that Kavanagh's The Great Hunger is "dead and oppressive" misses out on the poem's extensive ecological worth (Klejs 1983: 99). True, some lines from The Great Hunger do poeticize a natural universe that is at times dark, dismal, and unlush. But rather than characterize this chthonic habitat as "dead", it would be much more productive to recognize what Kavanagh makes possible in such confined topographic spaces; recognize that such entries bear witness to the woundedness of a land which contains, inside its unresuscitated ancestral discourse, the ecological legacies of what came before, during, and after "the Penal days".

While it is true, then, that Kavanagh sometimes give little quarter, it is equally true that his texts - ecological texts - embrace those natural wonders which converge in a world of marginal spaces where Kavanagh's people "learn to live without despairing" (Kavanagh 1964: 48). It is also true, as Seamus Heaney points out, that such nature narratives cannot be adequately understood in terms of English pastoral as defined (Heaney 1980: 115). When Terry Gifford writes that Kavanagh's "fatalistic despair" is akin to
Crabbe's it is therefore important for us to step back and ask if Gifford's mode of critical discourse provides an apt basis for examining Kavanagh's work (Gifford 1995: 69). The same might be said about some of Gifford's references to other Irish texts, for example, his reference to Heaney as an "inheritor of Wordsworth's legacy" which, as above, tends to obviate the native poet's right to define nature on his or her own terms.

Gifford's allied reference to John Montague's The Rough Field as a text that contains "envious evocations" of Samuel Palmer provides another example of virtual decontextualization (Gifford 1995: 43). Montague, himself, is quite clear that his townland (Garbh Achaid / Garvaghey / The Rough Field) stands in open contrast to the pastoral ward of the English canon: "No Wordsworthian dream enchants me here / With glint of glacial corry, totemic mountain. / But merging low hills and gravel streams" (Montague 1972: 13). Montague is just as clear that he wants to celebrate nature as something "serrated": "Let us not forget to celebrate / nature's strangeness. The serrated / length of the terrible predators" (Montague 1999: 62). $\mathrm{He}$ also makes it abundantly clear, with edge, that he has no time for Irish developers who destroy rural landscapes; expresses open contempt for the movers and shakers of County Tyrone with a sustained meditation on the "disappearance of all signs / of wild life" (Montague 1972: 58).

Although Seamus Heaney draws some important distinctions between the poetries of Montague and Kavanagh with respect to topographical/ecological matters, the most salient being that Heaney thinks Montague is much more "etymological" than Kavanagh (Heaney 1980: 140), he remains convinced that both writers share a certain narrative awareness - "what they have in common is a feeling for their place that steadies them and gives them a point of view" - which distinguishes them from the likes of Robert Lloyd Praeger: "just how vital this matter of feeling is we will see if we listen to an account of the Tyrone countryside by Robert Lloyd Praeger... His sense of place is, on the whole, that it is no place" (Heaney 1980: 144).

Here Heaney's critical line, a sectarian one, between Irish narratives as narratives of place and Anglo-Irish narratives as narratives of unplace, corresponds to the standard dualism 
as between an Irish (oral) tradition, on the one hand, and an Anglo-Irish (picturesque) tradition, on the other. It should come as no surprise, then, that Heaney differentiates his own poetic texts from those texts which belong to what he perceives to be a picturesque worldview. No surprise, either, that the natural world Heaney grew up in is, as he sees it, divided between a walled demesne ("the marks of English influence") and the "lure of native experience" ... an "apron of swamp on the west Bank of the River Bann" (Heaney 1980: $35)$.

Compared to the "lure of native experience" that appears in the nature poems of Heaney, Montague, Kavanagh, Northern Ireland's Protestant poets - and what follows is as preliminary as it is limited in scope - appear to inhabit somewhat different textual spaces within the North's competing ecological discourses. Louis MacNeice is just such a poet. A poet who returns, with panache, to that interstitial point (ecological) where he compares the wilderness he associates with Ireland to the spread of English woodland habitat: "when my father would frame / Escape, he thought, as I do, of bog or rock" (MacNeice 1967: 231). And, yet, as much as MacNeice makes it clear that he is drawn to Ireland's "bog or rock" it is interesting that he never identifies with the wilds of Mayo, his favorite holiday destination, in the same kind of referential mode that a Montague or Heaney might use to express deep-seated feelings about a particular townland.

Like MacNeice, Michael Longley is another Northern poet who, while he has furnished invaluable accounts of Ireland's assorted flora and fauna - often set in Mayo - does not so much rival the nature accounts of Heaney, Kavanagh, Montague, as stand across from them as an integer of a different mode of ecorepresentation. There is, in fact, a measure of watercolor promise to Longley's abundant species poetic that distinguishes it from the more drab species images - snipe, rats, etc. that inhabit the texts of Kavanagh et al. Whether we read the nature references Longley makes in "Irish Poetry," "Fuchsia's droop towards the ground, / The potato and its flower" (Longley 1985: 92), or, in ornithic turn, read his account of "The Ornithological Section," "We come as ornithologists - / As taxidermists we depart" (Longley 1985: 25), his accounts of the natural world unfold within a "picturesque" mode of reference that helps to situate and sustain his verse.

There are thus some grounds here - some to make a prima facie case that ecological difference serves as an extended and extenuating symptom of Ireland's intricate colonial experience and sectarian divisions. That said, we must now start to recognize just how much recent urban development, in conjunction with a growing awareness of multicultural and multiracial values, has enticed a number of Ireland's poets, both North and South (both Protestant and Catholic), to set off in interesting new directions so that the binary combination we have worked with so far - picturesque vs. oral - must face significant deconstructive challenge. A poet like Eamon Grennan (Rory Brennan says Grennan is "notable for the relentless avidity of his naturalist's eye") certainly represents such a shift in paradigm equation and deserves critical recognition for his up-close studies of plant and animal life (Brennan 1995: 25). Grennan also provides an overt ecological perspective which, in "Itinerary", yearns for a "hawk's high wide-angle lens / reading the world like a map" (Grennan 1998: 221). Just as "wide-angle", his close reading of birds in "Swifts over Dublin," "On a Cape May Warbler Who Flew against My Window" and "Stuffed Birds" deserve serious consideration as ornithic narratives à la mode (Grennan 1989: 10, 17, 29).

Sean Lysaght, another bird enthusiast Brennan argues that Lysaght's "spare scrupulosity is an antidote to Grennan's density" (Brennan 1995: 25) - also puts together some nice ornithological verses which include everything from peregrine falcons to woodcocks in The Clare Island Survey. Even as early as 1989, in the pages of Noah's Irish Ark, Lysaght set out to define himself as a naturalist who took "palaeo-paths / after Praeger and de Buitléar / into rugged interiors" (Lysaght 1989: 29) while insisting, at one and the same time, that his perspective was imagereflexive: "I can only become the thing I look for, / an image of these warped dwarf thorns, / wintering with the merlin" (Lysaght 1989: 18).

As well as Lysaght, there is now a growing number of poets who have compiled an impressive list of diverse and divergent nature lyrics. Works by Michael O'Loughlin, including The Diary of a Silence (1984) and Atlantic Blues (1985), demonstrate just such an 
overt interest in nature as an essential part of the poetic landscape. Peter Sirr, with his Marginal Zones and Ways of Falling, also has a few things to say about the "brittle politics of the forest floor": "Leaf-tides and birdsong, a fleeing hare's / Diminishing returns, and underfoot /The brittle politics of the forest floor" (Sirr 1984: 11). Consider, too, Maurice Riordan's A Word from the Loki (Riordan 1995), Padraig Rooney's In the Bonsai Garden (Rooney 1988), and Francis Harvey's The Rainmakers which considers, in "Blessings", the animate presence of trees: "I knew it for / the living thing it was under the palm / of my hand as surely as I know the living / sensuousness of flesh and bone" (Harvey 1988: 17).

If we add to these works the longstanding contributions of Harry Clifton and Thomas McCarthy it soon becomes apparent that nature represents a significant and signifying poetic subject in contemporary Irish literature. And for Clifton, at least, this means not only featuring nature as an important subject in itself, but, on a number of occasions - "Dry Savannah," Mango Season," "Savannah in Bloom" - it means inviting his readers to consider other geographical climes, to imagine foreign habitats, and to familiarize themselves with the unfamiliar (Clifton: 1979: 41, 44, 45). As for McCarthy, well, collections like The Sorrow Garden and The Lost Province feature an abundance of nicely textured nature lyrics while, in set pieces like "Grand Tour," the poet decides to turn back the clock and introduce us to one Charles Smith who, engaged in an "intellectual tour" of traditional Ireland, admits that he "noticed oaks / that flourished: but ignored the dark version / of landscape - the small holdings that crumbled / when those castles made their invasion" (McCarthy 1978: 37).

Other poets who merit some critical attention for their commitment to nature, as indispensable subject, include Gerard Donovan for Kings and Bicycles - "Limestone, like an intoned verse, / Rhymes down to a cliff" (Donovan 1995: 3) - Conor O'Callaghan for The History of Rain - "The way to the world is through trees" (O'Callaghan 1993: 22) and John O'Donohue for his Conamara Blues "May the contemplative mind of the mountain / Assure us that nothing is lost or forgotten" (O' Donohue 2001: 82). John Ennis also hosts some engaging ecological verses and defines, as he does in A Drink of Spring, Ireland as a place of dubious virtue: "Coyne, a new breed of farmer looks across your hedges. / Who will cut meadow in these acres in the year two thousand? / The vices of the country grow mean, its close-knit virtues meaner" (Ennis 1979: 13). Working in a similar ecological mode, Bernard O'Donoghue dwells on the eschatological value of "every square yard of land" and dreads what will happen if we all just sit back and watch "the green earth / Browning under unrelenting sun" (O'Donoghue 1987: 54). And then there is Geoffrey Squires who finds it increasingly difficult to even imagine an intact worldview which would help us put Ireland's "impossible" landscape back together again:

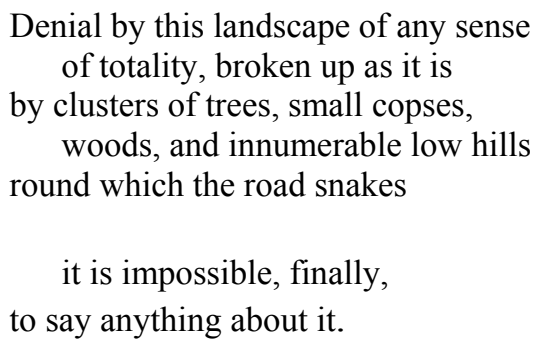

(Squires 1996: 39)

As early as 1972, Trevor Joyce - another writer who has contributed to a heightened awareness of the environment as poetic subject - wrote about nature in terms of "carrion" process: "anonymous carrion / was swathed in its own drowsy stench / putrefying into unity / with the gold, beautiful leaves" (Joyce 1972: 15). Later, in 1976, Joyce's interpretation of Buile Suibhne asks readers to think about certain irrepressible links between creature species in a world where "the ivy has no edge" (Joyce 1976: xiv). Joyce's Stone Floods added to such a "no edge" philosophy, in 1995, by introducing a set of postmodern angelics sent to watch over the threatened earth while "weeping to witness / such quick and irreversible decay" (Joyce 1995: 40-41). A kindred spirit in this "weeping to witness", Maurice Scully also envisions the natural world as a universe of close coordinates in "Four Corners" where he initiates an instructive exchange about the neo-negatives of pastoral: "It's / pastoral / When the grasslands disappear / \& the slopes are denuded" (Scully 1998: 54-5).

A like-sided definition of "pastoral" surfaces in the ecopoetics of Theo Dorgan who asks, in 
"Gaia", "Who would have chosen to live in these times, / On a planet ringed with fire, / The flood welling in her heart that will engulf us?" (Dorgan 1995: 57). Set against "these times, / On a planet ringed with fire" is the eco-theism of Sean Dunne who, in "One Sunday in the Gearagh," and "The Butterfly Soul" moves under the distant but watchful gaze of Thomas Merton and Simone Weil (Dunne 1996: 20-2, 25-6). A similar ecotheological disposition is also essential to Pádraig J. Daly who, as Augustinian priest, writes about the "spacelessness of God" and how "the raindrops / On the curlew's wing / Fall / As questions" (Daly 1999: 25, 27).

But, of course, no matter how much these poets might test Ireland's binary divisions - the oral/the picturesque - the predisposition of their ecological modes of writing still tends to reinforce certain key male or masculinist assumptions and so preclude women-based interpretations of nature; at the level of unconscious cultural exchange, sustain a longstanding ideological belief that nature is "female" in kind. Such an ideological belief is, to put it mildly, ironic - hyper-ironic if we stop to consider, as Kate Soper does in What Is Nature? Culture, Politics and the Non-Human, that it is only because of the feminist and ecological movements that we are now in any position to comprehend the "ideological parallels in the conception of nature as bestial 'other' to human culture, and the conception of woman as inferior 'other' to man" (Soper 1995: 122). Soper also reminds us, and this has clear implications when applied to the Irish situation, that the ideal feminization of the land has often served as a "prop for a reactionary politics" (Soper 1995: 123).

Carolyn Merchant lends credence to Soper's position with her concentrated eco-critique of sexual / textual politics in light of the Bible's Genesis narrative (Merchant 1995: 32). Put briefly, Merchant's critique faces down the presuppositional belief that in The Fall, Adam (an "innocent bystander") paid a huge price for Eve's feminine wiles and so had to "restore the garden" while Eve, as nature incarnate, had to be "tamed into submission" (Merchant 1995: 32). To substantiate her critique of Adamism, Merchant identifies several a priori scriptural traces that post a circumscribed view of women's place in the natural universe including what she refers to as original Eve, where nature is depicted as barren with some "potential for development," fallen Eve, where nature is perceived to be in a state of chaos, and, last but by no means least, mother Eve, where nature is depicted as a "nurturing earth bearing fruit" (Merchant 1995: 52).

Closer to home, we do not have to go very far to find ready illustrations of the same Adamic eco-traces at work. Even within the limited textual coverage that this article provides, Kavanagh's chthonic-sexual encounters with his townland and its priapic terms of reference, "The twisting sod rolls over on her back - / The virgin screams before the irresistible sock", typifies some of the same eco-priapic traces (Kavanagh 1972: 38). Every bit as symptomatic, consider how Synge anthropomorphizes the Aran Islands as a specific sexual site for him and other male interlopers in one of his notebooks as per The Aran Islands: "With this limestone Inishmaan ... I am in love, and hear with galling jealousy of the various priests and scholars who have lived here before me. They have grown to me as former lovers of one's mistress, horrible existences haunting with dreamed kisses the lips she presses to your own" (Robinson 1992: xiv).

Here, as elsewhere, Synge's sexualized sense of nature sets up specific gender inequalities as an intrinsic part of, and gloss on, human/nature relations which now need to be opened up to some rigorous criticism. One simple means of doing this, if only on a comparative basis, might be to explore narrative approaches other than those espoused by male authors; immediate example, spotlight Emily Lawless' account of the Aran Islands in Grania, a text which preceded Synge's account of the islands by several years (1892), and recognize how Lawless links the Aran Islands to what James M. Cahalan calls the "tragic victimization of its female protagonist" - consider, in detail, how she opposes "patriarchal domination of the natural world as well as male oppression of women" (Cahalan 1999: 33, 34).

Critics who sideline women nature writers like Lawless reinforce the false and misleading assumptions Soper and Merchant take issue with. Such critical sidelining - negligence also obviates the purposive eco-orientation that Lawless and other women writers have brought to bear on discussions of what nature is and how nature, if situated within an adaptive gender paradigm, might be read in far more gender-centered terms. It left unchallenged, on 
the other hand, such willful ignorance will continue to miss the o therwise simple point that many women writers, another prominent example being Katharine Tynan, have been shunted aside as mere subordinates; in Tynan's case as a subordinate of Yeats rather being viewed as a connoisseur of nature discourse in a language of her own choice.

Just check out the following titles, and this is nothing but a shortlist, of Tynan's variegated flora/fauna poems and ask how such an impressive list of ecological verses was ever ignored in the first place: "Starling", "Wings in the Night", "A Song of a Garden", "Sparrow", "The Blackbird in Town", "The Choir", "The First Cuckoo", "Larks", "Chaffinch", "Love at Easter", "Calling the Birds", "The Thrush and the Man", "The Making of Birds", "Blackbird", "Reconnaissance", "August Weather", "The Silent Time", "Poplar (I.)", "Poplar (II.)", "The Oak and the Man", "In the Green Wood", "Winter Trees", "The Tree" (Tynan 1930: 206-332). Also consider the fact that a long line of women writing at about the same time as Tynan recorded lyrics which have also been ignored because their poems, like Tynan's, were deemed - if deemed they were to be effete. One such writer is Susan Mitchell who incorporates, in her manner, the unassuming "buzz" of nature: "I buzz in the dizzy fly, I crawl in the creeping / things. / I croak in the frog's throat and fly on the bird's / wings" (Mitchell 1913: 23). Another poet who writes with a certain "buzz", this time as an astute ecological reference to trees in a hostile urban environment, is Eva Gore-Booth who reminds us that her political interests involve a language of nature:

The Elm boughs shudder in the sooty wind, From their bright leaves the City children know That somewhere the black world is glad and kind, And through green woods the sunlit breezes blow.

All starved and stunted from the poisoned sod, They shiver upwards through the stained air, These are the battered pioneers of God, Waving His green flag in the city square.

Thus in the grey-built city of the mind Wave the green boughs of a few hostage powers, Their secret whispered to the soilèd wind Hold all our faith in Beauty's austere flowers.
Somewhere the fair and secret troops of Spring Shine in strange colours icy clear and cold, But I pass on through dark streets wandering, Or dream a dream beneath the elm boughs old. (Gore-Booth 1995: 127)

Much as Gore-Booth finds it possible to talk about elm boughs shuddering "in the sooty wind", Rhoda Coghill garners enough space to publish some memorable nature lyrics in The Bright Hillside and fashion a provisional statement about how "All in Nature / Obeys an iron legislature" (Coghill 1948: 12-3). Not that long after Coghill published The Bright Hillside Eithne Strong started to write some poems including, though this is often overlooked, a number of hard-wrought nature lyrics. The most important of these nature references are to be found in Flesh ... the Greatest Sin which at certain crucial moments draws a clear line between picturesque / oral viewpoints while providing a counterweight, in terms of actuated gender difference, to the phallocentric gist of Kavanagh's Great Hunger: "Someway, she felt, their difference had to do / with owning big fields, knowing nothing about the ways of turf, / burning only coal, having orchards - in the bogs, fruit trees/ did not grow"(Strong 1980: iv).

Eavan Boland makes it clear in "The New Pastoral" that women have been dealt an unfair hand - have been placed under a virtual gag order - when it comes to writing about nature: "The first man had flint to spark. He had a wheel / to read his world (Boland 1995: 82). Unlike the "first man", Boland realizes that she is a "displaced person / in a pastoral chaos" and turns to nature as a suburban phenomenon: "the claustrophobia / Of your back gardens varicose / With shrubs make an ugly sister / Of you suburbia" (Boland 1980: 45). Eiléan Ní Chuilleanáin also writes in varicose codes that foster radical versions of a "new pastoral" and revels in alternate language episodes. But Ní Chuilleanáin does quite a bit more than just pass off nature as significant poetic cipher. Notice, in particular, how she evinces ("More Islands") a new narrative in a "storm of lemonade": "grows up to detest airports / But feels the sea in the waves of her hair / And icebergs in a storm of lemonade" (Ni Chuilleanain 1972: 16). Notice, too, how she manages ("Valerian") to set nature in an urban landscape where metal-workers "thrive": 
Dateflower, wild

In Dublin in July,

Dry red nodding above the lanes

Raglan Heytesbury Wellington Waterloo

Where the metal-workers thrive,

And there legged-up I stretched

To grasp their tough roots

Dry between the light mortar.

(Ní Chuilleanáin 1975: 32)

Nuala Ní Dhomhnaill also likes to write about the "tough roots" of nature as she does, and does so well, in "An Snag Breac" ("Ten Ways of Looking at a Magpie") where she expresses a deep concern about the spread of an invasive, i.e., non-native, avian species in shape of the Magpie which has dislodged native passerine species (Linnets) on the Dingle peninsula: "A mheaig a shnaig bhric / is mór é do chreach / ar na héanlaithe beaga" "Magpie, your black and white / has put to flight / every bird smaller than yourself" (Ní Dhomhnaill 1999: 50-53). A similar grá for nature, though in more urban light, is spelled out by Anne Hartigan in "Factory, Surrounded by Trees" where Hartigan writes about someone (a lone male figure) who has taken to the gentleness of arboreal forms: "but what I really wanted - / he looked down at his glass, / was to be with trees" (Hartigan 1986: 31).

Juanita Casey is another poet who has drawn a number of sensitive nature sketches including "Basking Shark, Achill" (Casey 1968: 10-11). Then there is Roz Cowman who, as it happens, is just as liable to assume the concerns of a peripheralized plant species as she is to issue an eco-rhetorical question - "So, you thought / your tarmac avenue / would smother me?" before offering a quick reminder that nature has a mind all its own: "Well, you forgot / the taproot / reaching yards down" (Cowman 1989: 17). Cowman, like so many other women poets in recent years - Lynda Moran, Rosemarie Rowley, Maeve Kelly, Sinéad Morrissey, Kerry Hardie, Ruth Carr, Joan Newmann, Moya Cannon - thus establishes and nurtures differential poetic locations wherein nature is allowed to become something other than.

All these narratives remind us that women, under conditions of de facto censorship, have registered a viable alternative to the Adamic strain that characterizes so many traditional ecological texts. And this desire to talk about the environment continues apace with Anne
Peters who laments that "Their machines burn the air we breathe, / and pour deadly wastes into rivers and oceans / until there is no seaweed / left in the surrounding surf" (Peters 1982: 20). Peters further asks, in "Presentiment in Beauty", if airplanes (as "triumph of man's technology") "presage a land where no bird flies?" (27). Audrey Scales, like Peters, has no time for the wanton destruction of habitat decrying, at one point, all the sudden growth in Ireland when she asks, in "The New Donegal", "Who brought this barren autobahn / To our lush island, / This Mid-West corral fencing / To windswept Ireland?"(Scales 1983: 5). At another point she is incensed by the fact that even in the late twentieth century ("Requiem for a Tree") people continue to wipe out what remains of their natural heritage: "I see / Power by proxy, / Clearance by the unseeing" (69).

So make no mistake. These variegated ecopoetic ventures - sans "Power by proxy" - are not part of the same old, same old. On the contrary, they signal a venture into the kind of unanticipated "blueberry / snake's head" Catherine Phil MacCarthy identifies in "The Omen" (MacCarthy 1991: 47). They also represent a deliberate attempt to inscribe new language occasions, eclipse standard categories, supersede established assumptions, override orthodox epistemological reference points and envision those things which transfigure the limits of what male/female discourse - ecological discourse - might become in the ripening of time.

Medbh McGuckian is quite right, then, to extenuate a "blueberry / snake's head" and question Ireland's established dualisms picturesque/oral, male/female, etc. - at length. What makes this all the more interesting, of course, is the fact that few (if any) of McGuckian's critics have targeted her frequent use of nature as an invaluable poetic talking point. Even Clair Wills, a critic who notes that McGuckian "stresses women's dispossession and their displaced relation to the land" (Wills 1993: 185) never gets down to analyzing such a "relation" in eco-centric terms. While Wills does - and she does - sometimes come close to generating a variant of ecocriticism as when she observes that McGuckian savors a poetic where the "oppositions between nature and culture" are unstable as a matter of choice (Wills 1993: 185), the potential for a rigorous and quite specific brand of "ecocriticism" is passed over in the interest of other critical 
concerns: no critical pressure is ever applied to the continuous idea that such lineal "oppositions" might provide a new hermeneutic approach for re-reading McGuckian's convex/concave nature narratives, morphological language species, mixed metaphoric habitats, and miscellaneous floral/faunal otherness.

To better understand the "oppositions between nature and culture", Ireland's critics must now begin to appreciate, in all seriousness, how when McGuckian inscribes "the womanliness / Of tulips with their beedark hearts" she is inscribing, as text, a species of ecological narrative as well as, and not instead of, her concerns as a woman poet (McGuckian 1980: 3). The same critics must also begin to appreciate just how often McGuckian's poems, for the sake of argument let's cite "Mr Mc Gregor's Garden", establish their own unique environmental schema by way of "resident toad", "handsome fungi", "dry-rot in the garden", "spiky purple heads among the moss" and "hedgehog's sleep" (McGuckian 1982: 14).

Ireland's critical establishment must also begin to make a good faith effort to acknowledge that the concentrated and continuous efforts of McGuckian (and others) to script a "flower's fragrance" (McGuckian 1982: 26) represents an important element in a novel and quite provocative brand of eco-erotic awareness. Just as McGuckian's tryst with nature requires much more critical analysis than it has received to date, it is also incumbent on us to work through the verses of a poet like Mary O'Malley and recognize how her conscientious sense of "The Sea Urchin" is eco-erotic in purpose: "Deep inside the shell she is exposed / And glows or shivers / In her soft pink flesh. / This is also where she cries / With her hundred crescent eyes" (O'Malley 1997: 37). It is also crucial that we check out, at a related level of eco-language practice, poets like Katie Donovan whose unique optique fuses together sophisticated ecological elements in Watermelon Man where she introduces her "Spider" as a means of expressing the intricate subtleties of oppression and interchange between species as metaphor, metaphor as species: "I open my mouth / and out she crawls, / the spider who's been hiding / down the pipeline / of my gullet" (Donovan 1995: 25). Later, in the same collection, Donovan uses several concomitant nature images to counter established gender roles and cast, in "Hunter", her protagonist-victim in a parched light:

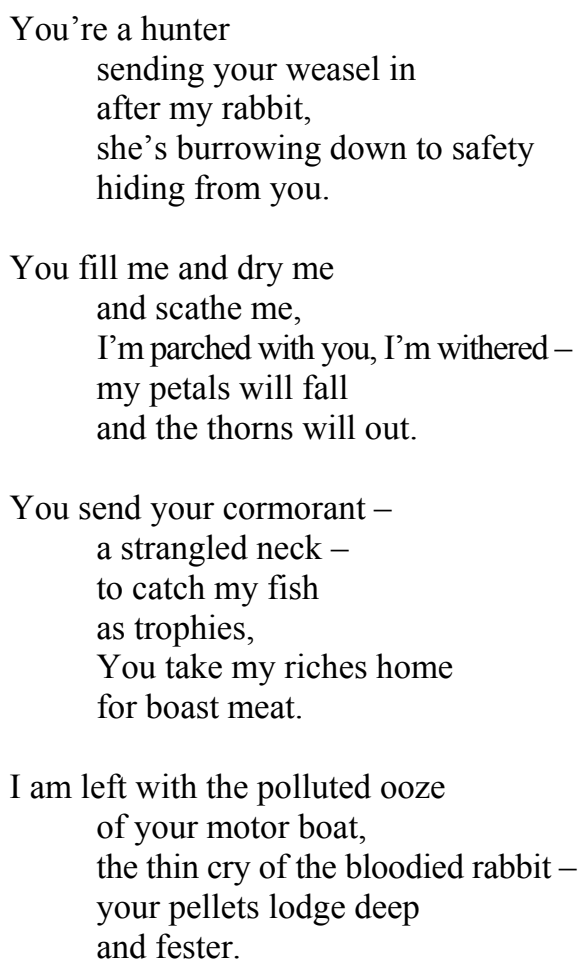

(Donovan 1995: 49)

If the argument here is (and it is) that what we call "nature" relies on a wide array of convergent but competing assumptions including more than a few gender assumptions - then how we read/write nature is crucial to the future politics of ecological discourse and environmental practice in Ireland. And in speculative terms, at least, this means that ecocritical discourse must incorporate more and more pointed questions related to how nature is perceived and what the politics of nature and culture, themselves intertwined terms of reference, hold in store for the next generation of Irish nature writers. Such emergent ecocritical theories must also incorporate the insights which come with, or, as sometimes happens, stand in opposition to, contemporary discourses and realize how such discourses, a nice example might be recent travel/tourist writing, define nature in the $21^{\text {st }}$ Century much as previous eco-narrative tracts - pieces of travel writing - like those of Synge and Yeats defined nature at the beginning of the $20^{\text {th }}$.

No less crucial, any emergent brand of ecocriticism must strive to incorporate (given Ireland's abysmal record on environmental protection and waste management) some broad- 
based discussions of what Lawrence Buell has referred to as "toxic" discourse whereby the "metaphorization of waste" - as "instructive analogue case" - might help to call into question received assumptions about the boundaries of "nature writing and environmental representation" (Buell 1998: 664). But perhaps most important of all, any emergent ecocritical theory must recognize what Dorinda Outram has made so clear in her article, "Negating the Natural: Or Why Historians Deny Irish Science" (Outram 1986: 47) - that Ireland's mainstream critics have failed to recognize how much critical discourse has itself marginalized and so ahistoricized man's and woman's encounters with nature to such a degree that the woundedness of Ireland's environmental experience now needs to be re-read in order to begin talking about "nature" in a new, unimpoverished light.

\section{Works Cited}

Birch, Thomas H. 1998. "The Incarceration of Wildness," in J. Baird Callicott and Michael P. Nelson (eds) The Great New Wilderness Debate. Athens: University of Georgia Press. 443-468.

Boland, Eavan. 1995. Collected Poems. Manchester: Carcanet.

Brennan, Rory. 1995. "Contemporary Irish Poetry: An Overview," in Michael Kenneally (ed), Poetry in Contemporary Irish Literature. Gerrards Cross: Colin Smythe. 1-27.

Buell, Lawrence. 1995. The Environmental Imagination: Thoreau, Nature Writing, and the Formation of American Culture. Cambridge, Mass: Belknap. 1998. "Toxic Discourse". Critical Inquiry 24. 639-665.

Cahalan, James M. 1999. Double Visions: Women and Men in Modern and Contemporary Irish Fiction. Syracuse: Syracuse University Press.

Cahill, Eileen. 1994. “'Because I Never Garden’: Medbh McGuckian’s Solitary Way”. Irish University Review 24.2. 264-271.

Cannon, Moya. 1990. Oar. Galway: Salmon. 1997. The Parchment Boat. Loughcrew, Oldcastle: Gallery Press.

Carr, Ruth. 1999. There is a House. Kilbeg, Kilcar: Summer Palace Press.

Casey, Juanita. 1968. Horse by the River and Other Poems. Dublin: Dolmen. 1985. Eternity Smith and Other Poems. Mountrath, Portlaoise: The Dolmen Press.

Clifton, Harry. 1979. Office of the Salt Merchant . Dublin: Gallery Press. 1994. Night Train Through the Brenner. Dublin: Gallery Press.

Coghill, Rhoda. 1948. The Bright Hillside.Dublin: Hodges, Figgis \& Co. 1956. Time is a Squirrel. Dublin: Dolmen.

Cowman, Roz. 1989. The Goose Herd. Galway: Salmon.

Daly, Pádraig J. 1999. The Last Dreamers: New \& Selected Poems.Dublin: Dedalus Press.

Donovan, Gerard. 1995. Kings and Bicycles. Galway: Salmon.

Donovan, Katie. 1995. Watermelon Man. Newcastle upon Tyne: Bloodaxe Books. . 1997. Entering the Mare. Newcastle upon Tyne: Bloodaxe Books.

Dorgan, Theo. 1992. The Ordinary House of Love. Galway: Salmon. . 1995. Rosa Mundi . Galway: Salmon.

Dunne, Sean. 1996. Time and the Island. Loughcrew, Oldcastle: Gallery.

Ennis, John. 1976. Night on Hibernia.Dublin: Gallery Press. . 1979. A Drink of Spring. Dublin: Gallery Press. 1985. The Burren Days. Dublin: Gallery Press. 1994. Down in the Deeper Helicon. Dublin: Dedalus Press. 1995. Telling the Bees. Dublin: Dedalus Press.

Foster, John Wilson. 1997. "The Culture of Nature" in John Wilson Foster (ed), Nature in Ireland: A Scientific and Cultural History. Dublin: Lilliput Press. 597-635.

1997. "Nature and Nation in the Nineteenth Century" in John Wilson Foster (ed), Nature in Ireland: A Scientific and Cultural History. Dublin: Liilliput Press, 409-439.

Forster, E.M. 1933. "Introduction” to Maurice O’Sullivan, Twenty Years A-Growing. Trans. Moya Llewelyn Davies and George Thomson. New York: Viking. 
Gifford, Terry. 1995. Green Voices: Understanding Contemporary Nature Poetry. Manchester: Manchester University Press.

Gore-Booth, Eva. 1995. Voices on the Wind: Women Poets of the Celtic Twilight. Eilís Ní Dhuibhne (ed), Dublin: New Island Books.

Grennan, Eamon. 1989. What Light There is \& Other Poems. San Francisco: North Point Press. . 1998. Relations: New \& Selected Poems. St. Paul: Graywolf Press.

Hardie, Kerry. 1996. A Furious Place. Loughcrew, Oldcastle: Gallery Press.

Hardy, Barbara. "Verge or Limit: Responses to Simple Nature," in Warwick Gould (ed), Yeats Annual No. 7. London: Macmillan. 68-80.

Hartigan, Anne. 1982. Long Tongue. Dublin: Beaver Row. . 1986. Return Single. Dublin: Beaver Row Press. 1991. Now Is a Moveable Feast. Galway: Salmon. 1996. Clearing the Space: A Why of Writing. Cliffs of Moher: Salmon.

Harvey, Francis. 1988. The Rainmakers. Dublin: Gallery Press. . 1996. The Boa Island Janus. Dublin: Dedalus Press.

Heaney, Seamus. 1980. Preoccupations: Selected Prose 1968-1978. London: Faber and Faber. 1979. Field Work. London: Faber and Faber.

Jackson, Kenneth Hurlstone. 1935. Studies in Early Celtic Nature Poetry. Cambridge: Cambridge University Press.

Joyce, Trevor. 1967. Sole Glum Trek. Dublin: New Writers’ Press, 1967. . 1969. Watches. New Writers' Press.

1972. Pentahedron. Dublin: New Writers' Press.

1976. The Poems of Sweeny Peregrine. Dublin: New Writers' Press.

1995. Stone Floods. Dublin: New Writers' Press.

1998. Syzygy. Bray: Wild Honey Press.

Kavanagh, Patrick. 1964. Collected Poems. New York: Devin-Adair.

. 1975a. Self-Portrait. $2^{\text {nd }}$ ed. Dublin: Dolmen.

1975b. The Green Fool. Harmondsworth: Penguin.

1978. Tarry Flynn. Harmondsworth: Penguin.

Kelly, Maeve. 1986. Resolution . Belfast: Blackstaff.

Lawless, Emily. 1897. Traits and Confidences.London: Metheun.

1901. A Garden Diary: September 1899-September 1900. London: Methuen, 1901.

1902. With the Wild Geese (1902)

1965. The Poems of Emily Lawless, ed., Padraic Fallon. Dublin: Dolmen.

1979. Grania: The Story of an Island, 2 Vols. New York: Garland, 1979.

Lene Klejs, Lene. 1983. "Seed Like Stars: Kavanagh's Nature”. Eire-Ireland 18.1. 98-108.

Lloyd, David. 1993. Anomalous States: Irish Writing and the Post-Colonial Moment . Dublin: Lilliput Press.

Longley, Michael. 1985. Selected Poems. Dublin: Gallery Press.

Lysaght, Sean. 1989. Noah's Irish Ark. Dublin: Dedalus Press.

. 1991. The Clare Island Survey. Loughcrew, Oldcastle: Gallery Press.

. 1998. Robert Lloyd Prager: The Life of a Naturalist. Dublin: Four Courts.

MacCarthy, Catherine Phil. 1991. How High the Moon. Dublin: Poetry Ireland.

McCarthy, Thomas. 1978. The First Convention. Dublin: Dolmen Press.

1981. The Sorrow Garden. London: Anvil Press.

1996. The Lost Province. London: Anvil Press.

McGuckian, Medbh. 1980. Portrait of Joanna. Belfast: Ulsterman Publications.

1982. The Flower Master. Oxford: Oxford University Press.

2001. Drawing Ballerinas. Oldcastle, Co. Meath: Gallery Press.

MacNeice, Louis. 1967. The Collected Poems of Louis MacNeice. Ed. E.R. Dodds. New York: Oxford University Press.

Merchant, Carolyn. 1995. Earthcare: Women and the Environment. New York: Routledge.

Meyer, Kuno. 1959. Selections from Ancient Irish Poetry. London: Constable. 
Mitchell, Susan. 1913. The Living Chalice and Other Poems. Dublin: Maunsel.

Montague, John. 1972. The Rough Field. Dublin: Dolmen. . 1999. Smashing the Piano. Loughcrew, Oldcastle: Gallery Press.

Moran, Lynda. 1985. The Truth About Lucy. Dublin: Beaver Row Press.

Morrissey, Sinéad. 1996. There Was Fire in Vancouver. Manchester: Carcanet.

Murphy, Richard. 2000. Collected Poems. Loughcrew, Oldcastle: Gallery. 2002. The Kick. London: Granta Books.

Newmann, Joan. 1995. Coming of Age. Belfast: Blackstaff Press.

Ní Chuilleanáin, Eiléan. 1972. Acts and Monument. Dublin: Gallery. 1975. Site of Ambush. Loughcrew, Oldcastle: Gallery Press. 1981. The Rose-Geranium. Dublin: Gallery Press. 1989. The Magdalene Sermon. Loughcrew, Oldcastle: Gallery Pres. 1994. The Brazen Serpent. Loughcrew, Oldcastle: Gallery Press. 2001. The Girl Who Married the Reindeer. Loughcrew, Oldcastle: Gallery Press.

Nic Dhiarmada, Bríona. 2008. "Utopia, Anti-Utopia, Nostalgia and Ó Cadhain”. The Canadian Journal of Irish Studies 34.1. 53-57.

Ní Dhomhnaill, Nuala. 1993. Pharaoh's Daughter. Winston-Salem NC: Wake Forest University Press. 1993. The Astrakhan Cloak. Winston-Salem NC: Wake Forest University Press. 1999. The Water Horse. Loughcrew, Oldcastle: Gallery Press.

O’Brien, James H. 1973. Liam O’Flaherty. Lewisburg: Bucknell University Press.

O’Callaghan, Conor. 1993. The History of Rain. Loughcrew, Oldcastle: Gallery Press.

O’Crohan, Tomás. 1934. The Islandman Robin Flower (trans), London: Chatto and Windus.

Ó Direáin, Máirtín. 1984. Selected Poems: Tacar Dánta. Trans. Tomás Mac Síomóin and Douglas Sealy. Dublin: Goldsmith.

O’Donoghue, Bernard. 1987. Poaching Rights. Dublin: Gallery Press 1995. Gunpowder. London: Chatto \& Windus.

O’Donohue, John. 1994. Echoes of Memory. Dublin: Salmon Press. .2001. Conamara Blues. New York: Harper Collins.

O'Flaherty, Liam. 1956. The Stories of Liam O'Flaherty. New York: Devin-Adair.

O’Loughlin, Michael. 1982. Atlantic Blues. Dublin: Raven Arts Press. 1985. The Diary of a Silence. Dublin: Raven Arts Press.

O’Malley, Mary. 1990. A Consideration of Silk. Galway: Salmon. .1997. The Knife in the Wave. Cliffs of Moher: Salmon.

Ó Tuama, Seán and Thomas Kinsella. 1981. An Duanaire/ 1600-1900: Poems of the Dispossessed. Mountrath, Portlaoise: Dolmen, 1981.

. 1995. Repossessions: Selected Essays on the Irish Literary Heritage. Cork: Cork University Press.

Outram, Dorinda. 1986. "Negating the Natural: Or Why Historians Deny Irish Science”. The Irish Review 1. $45-$ 49.

Peters, Anne. 1982. Rings of Green. Gerrards Cross, Bucks: Colin Smythe.

Power, Patrick C. 1967. The Story of Anglo-Irish Poetry, 1800-1922. Cork: Mercier.

Riordan, Maurice. 1995. A Word from the Loki. London: Faber and Faber.

Robinson, Tim. 1992. "Place/Person/Book" in J.M. Synge.The Aran Islands. Ed. Tim Robinson. London: Penguin, 1992. vii-1

Rooney, Padraig. 1988. In the Bonsai Garden. Dublin: Raven Arts.

Rowley, Rosemarie. 1985. The Broken Pledge and Other Poems. Dublin: Martello. 1987. The Sea of Affliction. Dublin: Rowan Tree Press. 1989. Flight into Reality. Dublin: Rowan Tree Press.

Sayers, Peig. 1981. Peig: The Autobiography of Peig Sayers of the Great Blasket Island. Dublin: Talbot Press. . 2000. An Old Woman's Reflections. Oxford: Oxford UP.

Scales, Audrey. 1983. The Ephemeral Isle. Limavady: Portmoon Press.

Scher, Amy. 1994. "Preaching An Ecological Conscience: Liam O’Flaherty’s Short Stories”. Eire-Ireland. 29.2. 113-122. 
Scully, Maurice. 1987. Five Freedoms of Movement. Newcastle upon Tyne: Galloping Dog Press. . 1988. Love Poems and Others. Dublin: Raven Arts. . 1998. Steps. London: Reality Street Editions.

Sirr, Peter. 1984. Marginal Zones. Dublin: Gallery Press. 1987. Talk, Talk. Dublin: Gallery Press. 1991. Ways of Falling. Loughcrew, Oldcastle: Gallery Press. 1995. The Ledger of Fruitful Exchange. Loughcrew, Oldcastle: Gallery Press.

Slater, Eamon. 1993. "Contested Terrain: Differing Interpretations of Co. Wicklow's Landscape”. Irish Journal of Sociology 3. 23-55.

Solnit, Rebecca. 1997. A Book of Migrations: Some Passages in Ireland. London: Verso.

Soper, Kate. 1995. What is Nature?: Culture, Politics and the non-Human. Oxford: Blackwell.

Squires, Geoffrey. 1996. Landscapes \& Silences. Dublin: New Writers' Press.

Strong, Eithne. 1980. Flesh ... the Greatest Sin. Dublin: Runa Press.

Synge, John Millington. 1992. The Aran Islands. Ed.Tim Robinson. London: Penguin.

Thompson, Richard J. 1983. “The Sage Who Deep in Central Nature Delves: Liam O’Flaherty's Short Stories”. Eire-Ireland 18.1. 80-97.

Tynan, Katharine. 1930. Collected Poems. London: Macmillan.

Viney, Michael Viney. 1986. "Woodcock for a Farthing: The Irish Experience of Nature". The Irish Review 1. 58-64.

Wilbur, Richard. 1976. Responses: Prose Pieces: 1953-1976. New York: Harcourt Brace Jovanovich.

Wills, Clair. 1993. Improprieties: Politics and Sexuality in Northern Irish Poetry. Oxford: Clarendon Press.

Yeats, W.B. 1976. Uncollected Prose, Vol. II., Ed., John P. Frayne and Colton Johnson. New York: Columbia University Press.

1982. 'Preface to the First Edition of The Well of the Saints' in J.M. Synge Collected Works: Volume III : Plays. Ed. Ann Saddlemeyer. Gerrards Cross, Bucks: Colin Smythe. 63- 68. . 1996. The Poems of W.B. Yeats. Ed. Richard J. Finnernan. New York: Macmillan.

Received 17 June $2010 \quad$ Last version 20 December 2010

James Mc Elroy, a graduate of Trinity College and University College, Dublin, currently teaches at the University of California, Davis. His articles and reviews have appeared in The New York Times, The Los Angeles Times, and The American Poetry Review. 